\title{
The Rethoric of Gender Mainstreaming During Covid- 19 Pandemic in North Sumatra
}

\author{
Asima Siahaan ${ }^{1},{ }^{*}$ Tunggul Sihombing ${ }^{2}$, Marhaeni Munthe ${ }^{3}$ \\ 1,2,3 Faculty of Social and Political Sciences, Universitas Sumatera Utara \\ Email: asimayantysiahaan@gmail.com
}

\begin{abstract}
This study aims at exploring the challenges to the implementation of gender mainstreaming in managing Covid-19 crisis in North Sumatra. It focuses on indicators in aspects of access, participation, control over resources and decision making, and the benefits of policies and programs for managing Covid-19 pandemic. This study is based on feminist qualitative research design. Data collection techniques included in-depth interviews, case studies, focused group discussions (FGD) and observation. Research informants consists of the local government and the Covid-19 Task Force, the Women and Children Empowerment Agency, Social Service, NGOs and women working in Medan and Siantar city. The findings reveal the handling of Covid-19 in North Sumatra ignores gender issues as evident by the absence of gender-based data in various Covid-19 handling programs, and the limited participation of women in crisis management related institutions. This study suggests the urgency of enhancing local government awareness, capacity and commitment in integrating gender in managing crisis as the key to the success of effective and equitable disaster management.
\end{abstract}

Keywords: gender mainstreaming, crisis management, pandemic

\section{INTRODUCTION}

The global Covid-19 pandemic has turned out to have resulted in different intensity of impacts among various components in society and further deepened pre-existing gender inequalities, increasing social, political and economic vulnerabilities which further exacerbated the impact of the pandemic [1] [2]. In a study on the impact of Covid-19 in Indonesia, poor women experience a worse quality of life decline than other groups in Indonesia because they are concentrated in the informal sector of work and unpaid domestic work [3]. Violence against women in Southeast Asia increased by $40 \%$ and in the Pacific it increased by 68\% [4]. The KOMNAS Perempuan report (2020) also mentions the increase in domestic violence and the increasing difficulty of women victims of violence and their companions getting services quickly due to the procedure for accessing Safe House services for women victims of violence during the Covid19 period with the complete requirements for a Covid-19 Free Letter [5].

Recognizing the gender-based impact of disasters, the Indonesian government has integrated gender into Law (UU) no. 24 of 2007 concerning Disaster Management. Gender is said to have a strategic position in disaster management as a principle and objective in the Act. PERKA Number 13 of 2014 concerning Gender
Mainstreaming in disasters as a legal basis for making policies, programs and budgets for disaster management from planning to implementation is gender responsive. However, based on research conducted by Siahaan and Tambunan [6] the low capacity of local governments in North Sumatra province to integrate gender in the planning, preparation, implementation, monitoring, and control of disaster management policies and programs has been a major obstacle in implementing gender mainstreaming in disaster management. nature that has ever happened in this area. With the issuance of Presidential Decree (KEPPRES) Number 12 of 2020 concerning the Determination of Non-Natural Disasters for the Spread of Corona Virus Disease 2019 (COVID19) as a National Disaster, PUG should be implemented in disaster management. North Sumatra Province is a disaster-prone area and includes an area with a high rate of Covid-19 cases. However, the handling of Covid-19 in North Sumatra still ignores gender issues as shown by the absence of gender-based data in various Covid-19 handling programs. It is very difficult to obtain data on the gender-based impact of Covid-19 in the province of North Sumatra. Gender mainstreaming in disaster management is very necessary to ensure the fulfillment of the rights and needs of men and women in a fair and humane manner. This study was aimed at obtaining an indepth description and analysis of the gender 
responsiveness of local governments in handling Covid19 in North Sumatra.

\section{LITERATURE REVIEW}

Gender mainstreaming is a process that can be used to integrate women's perspectives in risk reduction and disaster management. It serves as a gender analysis that identifies inequalities between women and men with regard to their rights, opportunities for self-development and access to resources in disaster management as part of the gender mainstreaming process [6]. Thus, gender mainstreaming is a strategy in making the needs and experiences of women and men an integral dimension in the design, implementation, monitoring and evaluation of policies and programs so that inequality between women and men is not further driven through processes in disaster management [7].

Local governments have an important role in ensuring gender mainstreaming in disaster and crisis management. Studies on the important role of local government in various regions show that equity in disaster management is achieved because local governments are closer to the population being served so that investment management and other financial resources are more effective for epidemic response, especially for marginalized population groups and those who are disadvantaged. in remote locations [8]. Local governments are more likely than the central government to expand epidemic response measures, such as providing better water and sanitation services to slum areas or personal protective equipment for street vendors, scavengers, and other informal sector workers [9][10]. The feminist approach explains the importance of the government's role by emphasizing their authority in formulating and implementing gender responsive budgets in ensuring women's access to employment, health, food and housing during the Covid19 pandemic [11].

The capacity of local governments in disaster management and building local community resilience to disasters, including integrating gender in gender mainstreaming strategies in disaster risk reduction and increasing local resilience is very important [12]. These capabilities include: strong government leadership and commitment to mainstreaming gender; the ability of institutions to guarantee women's representation; availability of gender analysis using gender sensitive data; availability of gender experts who understand gender policy design in the context of disaster management; and policies and program designs related to all aspects of disaster risk reduction and disaster resilience.

\section{METHOD}

This study is based on a feminist qualitative research design. The ability of qualitative research to capture how social interactions are routinely carried out is one of the strengths of qualitative research [13][14]. Therefore, feminist qualitative research is suitable for documenting the ways in which meanings are constructed and negotiated in particular social contexts [15]. This approach is crucial in understanding critical issues in gender mainstreaming in disaster management and providing in-depth explanations for research questions including the experiences of women in handling Covid19 in North Sumatra.

Data collection techniques include in-depth interviews, case studies, focus group discussions (FGD) and observation. Research informants consisted of local governments and the Covid-19 Task Force, the Women and Children Empowerment Agency, Disaster Management Agency and Social Service institution in Medan and Siantar City.

\section{RESULTS AND DISCUSSIONS}

\subsection{Ignorance of the urgency of gender mainstreaming}

Law No. 24 of 2007 on Disaster Management implies that disaster management is not only considered an emergency response issue, but includes everything from prevention to post-rehabilitation and reconstruction, which is integrated with development policies. The Law on Disaster Management has changed the paradigm of disaster management from responsive (centered on emergency response and recovery) to preventive (risk reduction and preparedness). However, in its implementation it still does not meet the mindset of sense of crisis where the intensity of planned and programmed disaster risk reduction programs is minimal. The issue that needs attention related to disaster management programs is that the orientation of activities is still more focused on handling emergencies and not yet on aspects of disaster risk prevention and reduction. In addition, an issue that is no less important is the issue of gender and marginalized groups where disaster management must reflect proportional justice for every citizen without exception and must not contain things that distinguish backgrounds, among others, religion, ethnicity, race,.class, gender, or social status.

This regulation emphasizes the fulfillment of the rights and needs of men and women in a fair and humane manner. This principle is shown concretely in its implementing regulations, namely Regulation of the Head of the National Disaster Management Agency (BNPB) No. 13 of 2014 concerning Gender Mainstreaming in the Field of Disaster Management. This regulation 2014 stipulates gender perspective in disaster management at all phases of disaster during predisaster, emergency response and post-disaster. Even in the planning of policies, programs and activities for 
disaster management, budgeting, and funding must be carried out in a gender perspective. The gender responsive activities carried out during pre-disaster include (1) conducting disaster risk studies, for example by using disaggregated data to assess differences in risk acceptance levels between men and women; (2) proportional vulnerability assessment, one of which is by mapping and documenting differences in gender-related vulnerabilities in physical, social, economic, cultural, political, security, and environmental aspects; (3) identification and assessment of capacity; (4) early warning; and (5) disaster mitigation and preparedness.

However there has been ignorance in understanding the realm and urgency of gender mainstreaming in managing the Covid-19 pandemic. Regulation of the Head of BNPB Number 13 of 2014 concerning Gender Mainstreaming (PERKA PUG) in Disaster Management, is still not the basis for the work of the Covid-19 Task Force, and all levels of government, while Permendagri No. 15 of 2008 in article 4 paragraph (1) which mandates that local governments are obliged to formulate policies related to PUG. The policy for the establishment of the Provincial PUG Working Group is determined by a Governor's Decree (Article 4 paragraph (4).

There are differences in understanding gender mainstreaming and its implementation in handling Covid-19. In general, local government institutions still view gender mainstreaming as synonymous with programs and activities for women. As a result, women's strategic interests are still marginalized. The absence of Perka BNPB Number 13 of 2014 had a serious impact on several things. First, the lack of representation of women in the COVID-19 Task Force starting at the national, regional and village levels. Meanwhile, Article 17 of the PERKA document stipulates the need for balanced representation between women and men to be involved. This is shown by the very minimal number of women in the structure of the COVID-19 Handling Task Force of North Sumatra Province.

\subsection{Lack of coordination}

Sectoral ego in handling covid-19 is also seen from local government's indecisiveness in carrying out coordination between the health workers and the institutions related to managing Covid-19 health crisis. There has been frequent miscommunication between surveillance (Community Health Centers) who carry out data collection and those who conduct sample collection (tracking). There are cases when the health office inform there was one patient who would be tracked but when the health field worker went to the field it turned out that in one house only one person was reported positive even though the occupants of the other house were also exposed to Covid. However, in reports and data collection from the Health Office to BPBD only one was recorded, while positive family members were not followed up.
The sectoral ego of a number of agencies is also seen, one of which is in the process of examining specimens in laboratories that have not been integrated. The results of the laboratory examination must also be reported directly to the task force for the acceleration of handling Covid19. Thus, the data submitted to the public becomes coherent and more accurate. This causes no synchronization between field data and data published by the health department. In handling COVID-19, we must prioritize data transparency, appropriate and independent policies, comprehensive, and not dependent on the influence of someone or something, building trust in the public, and effective communication are the keys that we see based on comparisons with other countries.

One of the obstacles to coordination between agencies is the dual function of the bureaucracy which causes the bureaucracy to become Overlapping. The focus between the Social Service Office and the PPA Sector is certainly different. Gender Mainstreaming focuses on the involvement and focus of women in development. The Department of Social Affairs is not primarily responsible for implementing the gender mainstreaming strategy in terms of women's empowerment. That is the task and function of the PPA Division, which in Medan City, Binjai City, and several other areas in North Sumatra has become a separate Service (Department of Women's Empowerment and Child Protection).

Coordination that is not well established is the reason for the failure of Gender Mainstreaming during the crisis in Pematangsiantar City. The bureaucratic structure that is incompatible with the needs of the community contributes to the challenges in coordinating gender mainstreaming during the crisis. Whilst women are the pillars of the Covid-19 disaster management and at the same time receive more impacts from the Covid-19 pandemic, the women's empowerment and child protections division has very limited power and authority due to low bureaucratic position as part of Social Service agency. This condition further increase the ignorance of the urgency in gender mainstreaming the Covid-19 pandemic crisis management in North Sumatra.

\section{CONCLUSIONS}

Applying a gender perspective in handling COVID19 means understanding that the experience of going through a crisis for vulnerable groups according to categories is fundamentally different from one another, so that the responses given also have different impacts. In fact, based on the pandemic incident in North Sumatra, the response to COVID-19 still fails to implement a gender perspective, even though the ability of the government and policy makers to apply gender glasses has implications for physical security for women (health workers). Policy makers can design different policies using a gender perspective rather than using a neutral 
approach in their efforts to respond to and recover from the impact of the pandemic.

The government must focus on monitoring policies that are relevant to the prevention of COVID-19 so that they run by using the principles of human rights, gender justice, being implemented effectively, adaptive to local needs, participatory and taking into account all forms of vulnerability in the community. Considering the vast ignorance of the urgency of gender mainstreaming among local government institutions, head of local governments need to have strong disposition in enforcing, monitoring and evaluating the implementation of gender mainstreaming by driving synergetic partnerships in utilizing all resources and capacities.

\section{AUTHORS' CONTRIBUTIONS}

Each author has equal contribution to this research.

\section{ACKNOWLEDGMENTS}

The authors gratefully acknowledged that the present research is funded by the Directorate of Research and Community Service of the Ministry of Research and Technology / National Research and Innovation Agency for the Fiscal Year 2021 under the Research and Community Service Funding Agreement for the Fiscal Year 2021 with contract number 12/EI/KP.PTNBH/2021, March 8, 2021

\section{REFERENCES}

[1] Baird, Marian (2020). COVID-19 and Women's Economic Participation. A rapid analysis on COVID-19 and implications for women's economic participation.The Women and Work Research Group The Australian Women's Working Futures Project. The University of Sydney Business School. sydney.edu.au/business/research/wwrg

[2] Weforum (2020). COVID-19 highlights how caregiving fuels gender inequality. https://www.weforum.org/agenda/2020/04/covi d-19-highlights-how-caregiving-fuels-genderinequality.

[3] Samudra, Reksa dan Setyonaluri (2020). Policy Report | Inequitable Impact of COVID-19 in Indonesia: Evidence and Policy Response. https://en.unesco.org/inclusivepolicylab/sites/de fault/files/analytics/document/2020.

[4] UN Women (2020). Unlocking The Lockdown. The Gendered Effects Of Covid-19 On Achieving The Sdgs In Asia And The Pacific. https://data.unwomen.org/publications/unlockin g-lockdown-gendered-effects-covid-19achieving-sdgs-asia-and-pacific
[5] 5. Iswarini,Theresia Sri Endras (ed.) (2020. Melayani Dengan Berani : Gerak Juang Pengada Layanan Dan Perempuan Pembela HAM Di Masa Covid-19. Komnas Perempuan: Jakarta

[6] UN/ECOSOC. (1997). Gender Mainstreaming. Report Of The Economic And Social Council For 1997

Https://Www.Un.Org/Womenwatch/Daw/Csw/ Gms.Pdf

[7] Enarson, E. and Chakrabarti, PGD. (2009). Women, Gender, and Disaster, Sage Publication Privat Limited: India.

[8] OECD. (2020). Women at the core of the fight against COVID-19 crisis. Diakses dari https://www.oecd.org/coronavirus/policyresponses/women-at-the-core-of-the-fightagainst-covid-19-crisis-553a8269/

[9] Makha. (2020). Adopt Gender Responsive Governance To Address Covid. Diakses dari https://genderlinks.org.za/news/adopt-genderresponsive-governance-in-addressing-covid-19/

[10] Dutt, Kuntala Lahiri-.(2020). Gender in Post Covid - 19 development Policy. Looking through a feminist lens..diakses dari https://www.policyforum.net/gender-in-postcovid-19-development-policy

[11] Viswanath, Shilpa \& Lauren Bock Mullins (2020): Gender responsive budgeting and the COVID-19 pandemic response: a feminist standpoint, Administrative Theory \& Praxis, https://www.tandfonline.com/doi/full/10.1080/1 0841806.2020 .1814080

[12] UNISDR. (2012) International Day for Disaster Reduction Report, 'Women and Girls the Invisible Force of Resilience' diakses dari http://www.unisdr.org/2012/iddr/docs/Final_Co nceptNote Annexes.pdf

[13] Denzin, Norman dan Lincoln (eds), 2009 Handbook of Qualitative Research. Pustaka Pelajar: Yogyakarta

[14] Tracy. Sarah J (2014). Qualitative Reseach Methods. Collecting evidence, Crafting analysis, Communicating IMpact. Blackwell Publishing:UK

[15] Holdaway, Simon (2000) 'Theory and method in qualitative research', pp.156-166 in Dawn Burton ed. Research Training for Social Scientists Sage Publications, London 